\title{
Demulsification Treatment of Spent Metalworking Fluids by Metal Cations: The Synergistic Effect and Efficiency Evaluation
}

\author{
Yanqing Zhang ${ }^{1,+}$, Lingxue $\mathrm{Wu}^{1,+}$, Xiaochen Zhang ${ }^{1}$, Baoxin $\mathrm{Ge}^{2}$ and Yuanfeng Qi ${ }^{1,2, *}$ \\ 1 School of Environmental and Municipal Engineering, Qingdao University of Technology, \\ Qingdao 266033, China; zyq_luck@163.com (Y.Z.); wulingxue1121@163.com (L.W.); \\ zhangxiaochen1214@163.com (X.Z.) \\ 2 Jiangsu ATK Environmental Engineering Co., Ltd., Wuxi 214214, China; gebx_ujn@163.com \\ * Correspondence: qiyuanfeng@qut.edu.cn \\ + These authors contributed equally to this work.
}

Citation: Zhang, Y.; Wu, L.; Zhang, X.; Ge, B.; Qi, Y. Demulsification Treatment of Spent Metalworking Fluids by Metal Cations: The Synergistic Effect and Efficiency Evaluation. Processes 2021, 9, 1807. https://doi.org/10.3390/pr9101807

Academic Editors: Jacek Gebicki, Pawel Sobieszuk and Piotr Rybarczyk

Received: 30 August 2021

Accepted: 30 September 2021

Published: 12 October 2021

Publisher's Note: MDPI stays neutral with regard to jurisdictional claims in published maps and institutional affiliations.

Copyright: () 2021 by the authors. Licensee MDPI, Basel, Switzerland. This article is an open access article distributed under the terms and conditions of the Creative Commons Attribution (CC BY) license (https:// creativecommons.org/licenses/by/ $4.0 /)$.
Abstract: In this paper, various metal ions were utilized for the demulsification of spent metalworking fluids discharged from an automobile parts workshop. Five types of metal ions, i.e., $\mathrm{Fe}^{3+}, \mathrm{Al}^{3+}, \mathrm{Fe}^{2+}$, $\mathrm{Ca}^{2+}$ and $\mathrm{Mg}^{2+}$, combined with coagulant were systematically evaluated, and the synergistic effect as well as the optimum operating conditions were studied. The results indicated that the $\mathrm{Ca}^{2+}$ as well $\mathrm{Mg}^{2+}$ possessed hardly efficiency for the demulsification, on the contrary, $\mathrm{Fe}^{2+}$ reduced the yield of the by-product sludge and lowered the $\mathrm{SV}_{30}$ ratio, and $\mathrm{Al}^{3+}$ boosted the $\mathrm{COD}_{\mathrm{Cr}}$ removal. Furthermore, $\mathrm{Fe}^{3+}$ and $\mathrm{Al}^{3+}$ had a significant synergistic effect to achieve a better transmittance and a higher $\mathrm{COD}_{\mathrm{Cr}} / \mathrm{SV}_{30}$ ratio which revealed that more $\mathrm{COD}_{\mathrm{Cr}}$ was removed, as well as less by-product sludge was generated. For a better demulsification of spent metalworking fluids, the optimum operating conditions were gathered as follows: the dosage of metal ions was $0.08 \mathrm{~mol} / \mathrm{L}$ with $\mathrm{Al}^{3+}: \mathrm{Fe}^{3+}$ ratio was $1.5: 1$, the reaction $\mathrm{pH}$ was 6.00 , the reaction time was $18.00 \mathrm{~min}$ and the temperature was $323.00 \mathrm{~K}$. Based on this, the $\mathrm{COD}_{\mathrm{Cr}}$ removal, the $\mathrm{SV}_{30}$ ratio and the transmittance and $\mathrm{COD}_{\mathrm{Cr}} / \mathrm{SV}_{30}$ ratio of the spent metalworking fluids were $80.21 \%, 40.00 \%, 95.20 \%$ and $128.33 \mathrm{mg} / \mathrm{mL}$, respectively. This combined metal ion demulsification method possessed an advantageous minimization of spent metalworking fluids, which greatly benefited the automobile parts workshops in cutting down the operating cost in environmental protection.

Keywords: spent metalworking fluids; demulsification; synergistic effect; efficiency evaluation; hazardous waste minimization

\section{Introduction}

Metalworking fluids (MWFs), which are a complex of oiling, surfactants and a variety of functional additives in accordance with a certain proportion of fusion, are abundantly utilized in the manufacturing domain and exert outstanding cooling, lubrication, anti-rust and anticorrosion protection functions [1,2]. Practically, after a long duration of repeating, attributed to the oil emulsion, residual metal chips, bacteria and the mix foreign material, the MWFs will gradually age, deteriorate and corrupt [3]. Those long-used metalworking fluids are not only hazardous to the equipment but also emit a foul odor throughout the manufacturing workshop, which worsens the atmosphere conditions as well as the work environment [4]. Therefore, in order to maintain the beneficial operating conditions, new MWFs should be frequently added to substitute a portion of the longtime-used MWFs (L-MWFs) [5].

According to China's National Hazardous Waste List (2021 edition), L-MWFs are the most significant waste discharged from the manufacturing workshop, which are labeled as Hazardous Waste (HW09, 900-006-09) [6]. Consequently, those hazardous wastes were forbidden to be discharged into the environment and should be strictly supervised and safely 
treated by specific organizations, which increases the operating cost of the manufacturing workshops [7].

L-MWFs are rich in high-concentration and high-stability emulsified oil pollutants [8]. Before the traditional wastewater treatment method (for instance, various AOP techniques $[9,10]$, bio-treatment [11], etc.) was carried out, the demulsification of those emulsified oil pollutants played a key role throughout the L-MWFs' treatment. Currently, common demulsification methods mainly included chemical (such as the addition of organic demulsification [12,13], acidified demulsification [14] and inorganic demulsification [15]), physical (such as thermal demulsification [16], ultrasonic demulsification [17] and membrane demulsification [18]) and the combined physical-chemical method, among which the chemical demulsification methods are the main technology for demulsification at present by virtue of their low investment cost and excellent efficiency. Specifically, (i) organic demulsification means that the water and oil are layered through adding specific organic demulsifiers (such as polymeric flocculant and surfactant [12]), however, the screening process of the demulsifier was so tedious that the efficiency was difficult to remain stable against the complex emulsified oil mixtures such as L-MWFs; (ii) the acidified demulsification [14] was accomplished by the neutralization of the diffused anionic emulsifier by protons discharged under acid conditions; nevertheless, the demulsification efficiency was relatively poor, and the $\mathrm{pH}$ environment was seriously corrosive to the equipment in extreme cases; (iii) the inorganic demulsification mainly carried out by the electrolytes (such as ferrous chloride, calcium chloride, polymeric aluminium and polyferric chloride, etc., [19] as well as the reinforced, oriented, additional and inorganic flocculant), similarly to the organic demulsification, had a functional metal ion screening process that was complex, which led to less reports on the inorganic demulsification screening for L-MWFs. Furthermore, the synergistic demulsification of organic demulsification and inorganic demulsification, or the combined demulsification of metal cation was proved as a promising way to improve the removal rate of oil pollutants and $\mathrm{COD}_{\mathrm{Cr}}$ [20]. Unfortunately, the synergistic effect of bi-metal salt demulsification on L-MWFs demulsification with high pollutant content and complex ingredients was rare at present.

In addition, in the evaluation index aspect, the investigation of the supernatant properties after demulsification is concerned at present, and $\mathrm{COD}_{\mathrm{Cr}}$ was considered as the cored control index, which has been reported elsewhere [7], but the study on the yield of sludge (which was the main by-product) was less reported. According to the requirements of the Directory of National Hazardous Wastes List [6], the by-product sludge is to be considered as hazardous waste, even if it is demulsified, which means not only the oil pollutants should be removed in the actual project but the yield of sludge should also be reduced. Therefore, we recommend that the demulsification process of the removal of oil pollutants in L-MWFs and the generation of secondary sludge should be considered as a whole, but the point of view has still been short of a targeted report up to now.

In order to overcome the drawbacks mentioned above, in this paper, the inorganic demulsifier in the demulsification process of L-MWFs was screened and evaluated with the addition of polyacrylamide as a reinforced demulsifier. In terms of ion optimization, firstly, the demulsification effect of mono-metal cation L-MWFs was systematically scrutinized by a variety of common metal ions; secondly, the effect of the combined demulsification of bi-metal cations was studied to define the synergistic effect between ions; thirdly, based on the bi-metal combined reinforced demulsification method, a group of operating parameters of one of the advanced formulations was optimized for the L-MWF demulsification. In terms of evaluation indicators, the supernatant properties and the amount of by-product bottom sludge after demulsification have been simultaneously paid attention to. So far, there is almost no literature on by-product sludge in the demulsification process. Secondly, in order to eliminate the interference of ion concentration and distinguish the difference in the demulsification effect of different metal ions in L-MWFs, a normalized ion strength was applied to evaluate the demulsification results for the first time. In addition, a compre- 
hensive evaluation index, which was used to evaluate the effectiveness and economy of demulsification, was proposed.

In addition, the MWF's global consumption was more than $1 \times 10^{7} \mathrm{t} /$ year [21], according to the use of a $10 \%$ dilution ratio, the L-MWFs emissions were about $1 \times 10^{8} \mathrm{t} /$ year, and as the size of machining industry expands, that number will only increase. This has brought great pressure to environmental protection work, and to realize the disposal of L-MWFs with low investment and low operation cost was the goal pursued by machining enterprises and environmental protection workers. This study provides a timely demulsification method with an attractive economy.

\section{Materials and Methods}

\subsection{Agents and Materials}

Five types of common metallic salts, i.e., $\mathrm{AlCl}_{3}, \mathrm{FeCl}_{3} 6 \mathrm{H}_{2} \mathrm{O}, \mathrm{FeCl}_{2} 4 \mathrm{H}_{2} \mathrm{O}, \mathrm{CaCl}_{2}$ and $\mathrm{MgCl}_{2}$, were utilized as the inorganic demulsifiers (CP, Shanghai Macklin Biological Reagent Co., Ltd. (Shanghai, China)). The above reagents were placed in the drying oven protected by nitrogen at $105^{\circ} \mathrm{C}$ for $5 \mathrm{~h}$ until a constant weight before use, and then the solution with initial concentration of each metal of $2 \pm 0.02 \mathrm{~mol} / \mathrm{L}$ was prepared at room temperature and preserved in brown reagent bottles for standby. The polyacrylamide (PAM, anionic, molecular weight: 10 million; China National Pharmaceutical Group Co., Ltd. (Shanghai, China)) was used as the demulsified reinforcer, and $1 \mathrm{~mol} / \mathrm{L} \mathrm{HCl}$ and $1 \mathrm{~mol} / \mathrm{L} \mathrm{NaOH}$ were used as the control agents of $\mathrm{pH}$ in the experimental process.

The demulsification object L-MWFs were taken from a processing and manufacturing workshop of stainless-steel S316L automobile parts. The stainless-steel scraps and other impurities inside were filtered by 200-mesh screen at room temperature and stand for $48 \mathrm{~h}$, and then they were kept in sealed reagent bottles after the surface oil slick was removed by separating funnel. The images of L-MWFs before and after pretreatment were illustrated in Figure S1.

\subsection{Analysis Method}

The conductivity and $\mathrm{pH}$ were determined by multi-parameter analyzer (DZS-708, Shanghai Lei-ci Instrument Co., Ltd. (Shanghai, China)). $\mathrm{COD}_{\mathrm{Cr}}$ was determined by a Water-Quality analyzer (DR2000, Hach Instrument, Loveland, CO, USA). The transmittance was determined by ultraviolet and visible spectrophotometry (UV-6000PC, Shanghai Metash Instruments Co., Ltd. (Shanghai, China)) at $500 \mathrm{~nm}$. The $\zeta$ potential and particle size were determined by nanoparticle size tester (Litesizer 500, Anton Paar Shanghai Co., Ltd. (Shanghai, China)), and the $\mathrm{SV}_{30}$ ratio was tested by referring to the China National Standard [22]. The test methods mentioned above were as shown in S1. Additionally, the average value of each index was taken through parallel testing three times.

\subsection{Demulsification Method}

It was demulsified in the self-made reactor (Figure 1) and consisted of 8 cylinders equipped with adjustable speed magnetic rotor and scale $(250 \mathrm{~mL}, 7$ cylinders as experimental group and 1 cylinder as control group), time controller and temperature controller.

The procedure was carried out as follows: $100 \mathrm{~mL}$ L-MWF was firstly injected to each cylinder in the beginning of demulsification experiment. Then, the inorganic demulsifiers with different ion concentrations were added and started counting after the adjustable speed magnetic rotor was controlled to 500RPM until stable. After being reacted for a specific time, the stirring speed was reduced to 80RPM, and $0.5 \pm 0.02 \mathrm{~mL}$ PAM (mass concentration: $0.01 \%$ ) was added and counted. It stood for $30 \mathrm{~min}$ after reaction, the volume of sludge was recorded and the $\mathrm{SV}_{30}$ ratio (Equation (1)) was calculated. Lastly, the supernatant was filtered by $0.45-\mathrm{um}$ membrane and tested. Equation (1) is calculated as follows:

$$
\mathrm{SV}_{30} \text {-ratio }=\frac{V_{S}}{V_{S}+V_{L}} * 100 \%
$$


where,

$\mathrm{SV}_{30}$ ratio: Volume ratio of sludge after standing for $30 \mathrm{~min}$ (in percentage, \%);

$V_{S}$ : Volume of sublayer sludge $(\mathrm{mL})$;

$V_{L}$ : Volume of supernatant liquid $(\mathrm{mL})$.

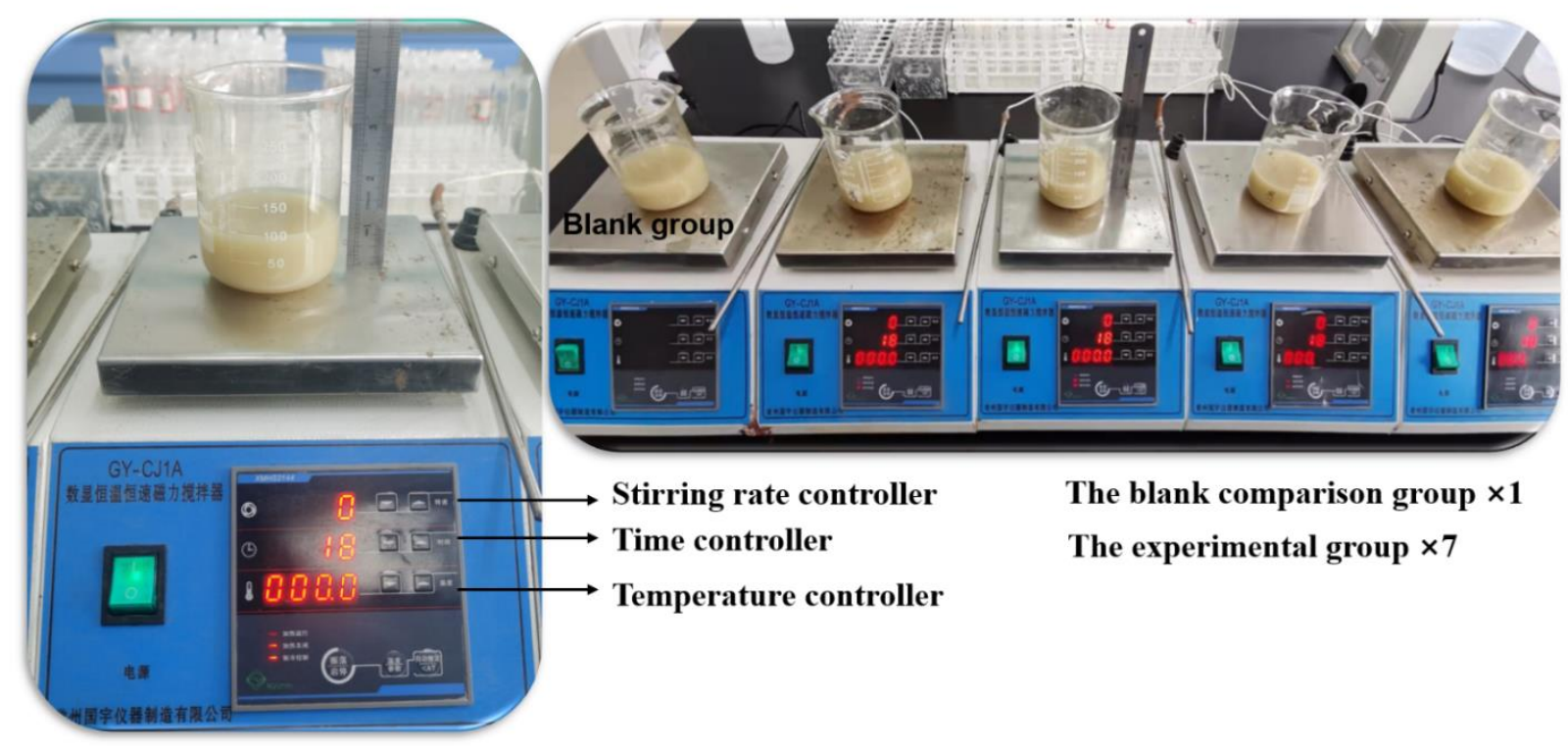

Figure 1. Self-made reactor, the illustrated image above was the specific construction of the reaction equipment.

\section{Results and Discussion}

\subsection{Properties of the L-MWFs}

The L-MWFs were constant of greyish-green liquid before the pretreatment (Figure S1), and there was flowed liquid with a black oil slick on surface, which emitted an intense, pungent odor. The properties of the L-MWFs after pretreatment are presented in Table 1. The oil pollutants existed in the emulsified form, which caused the transmittance to be less than $0.03 \%$; the $\mathrm{COD}_{\mathrm{Cr}}$ contained in the L-MWFs was $6.2 \times 10^{4}-6.4 \times 10^{4} \mathrm{mg} / \mathrm{L}$, the initial $\mathrm{pH}$ was $8.50 \pm 0.05$, the particle size was $754.50-779.40 \mathrm{~nm}$ and the conductivity was $15.60 \pm 0.04 \mathrm{mS} / \mathrm{cm}$. Therefore, an $\mathrm{O} / \mathrm{W}$ state existed, among which the oil phase was dispersed and the continuous phase was water. The $\zeta$ potential of the L-MWFs was $-74.61--72.81 \mathrm{mV}$. According to the colloidal stability theory [23-25], when the absolute value of the $\zeta$ potential was more than $30 \mathrm{mV}$, it showed that the emulsified liquid was relatively stable. It showed very strong electronegativity according to the negative value of $\zeta$, which indicated that the L-MWFs were emulsified by an anionic surfactant [2], and the residual oil drops of the L-MWFs formed stable interfacial films through anionic surfactants so that the oil was evenly dispersed in water.

Table 1. Features of the L-MWFs.

\begin{tabular}{|c|c|c|}
\hline Features & Values & Unit \\
\hline Transmittance & $<0.03$ & $\%$ \\
\hline $\mathrm{COD}_{\mathrm{Cr}}$ & $6.20 \times 10^{4}-6.40 \times 10^{4}$ & $\mathrm{mg} / \mathrm{L}$ \\
\hline $\mathrm{pH}$ & $8.50 \pm 0.05$ & - \\
\hline Mean particle size & $754.50-779.40$ & $\mathrm{~nm}$ \\
\hline Conductivity & $15.60 \pm 0.10$ & $\mathrm{mS} / \mathrm{cm}$ \\
\hline$\zeta$-potential & $-74.61--72.81$ & $\mathrm{mV}$ \\
\hline
\end{tabular}




\subsection{Effect of Mono-Metal Cation on L-MWFs Demulsification}

Based on the $\mathrm{COD}_{\mathrm{Cr}}$ removal (\%), the $\mathrm{SV}_{30}$ ratio (\%), the transmittance (\%) and the $\mathrm{COD}_{\mathrm{Cr}} / \mathrm{SV}_{30}$ ratio $(\mathrm{mg} / \mathrm{mL})$ as an index, the demulsification effect of five metal ions, including $\mathrm{Fe}^{3+}, \mathrm{Fe}^{2+}, \mathrm{Al}^{3+}, \mathrm{Ca}^{2+}$ and $\mathrm{Mg}^{2+}$, was as shown in Figure 2.
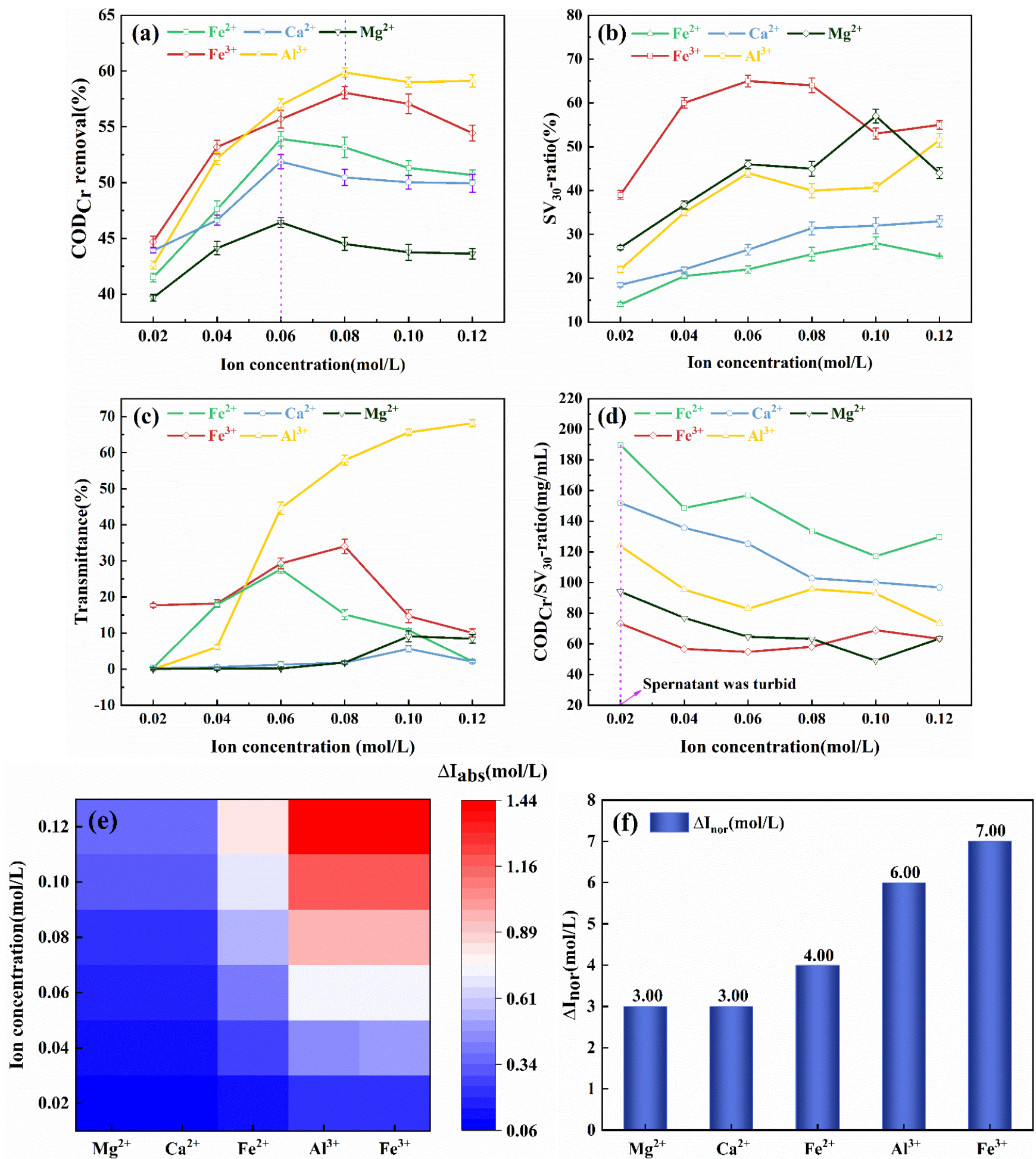

Figure 2. Effect of mono-metal ion on demulsification of L-MWFs: (a) $\mathrm{COD}_{\mathrm{Cr}}$ removal, (b) $\mathrm{SV}_{30}$ ratio, (c) transmittance, (d) $\mathrm{COD}_{\mathrm{Cr}} / \mathrm{SV}_{30}$ ratio, (e) differential ion strength, (f) normalized ion strength. The fixed process conditions of the above experiments were as follows: temperature was $283 \mathrm{~K}$ (Room temperature), $\mathrm{pH}$ was 8.50 (Initial pH of L-MWFs), stirring time was $18 \mathrm{~min}$. 
With the increased in the concentration of five ions, the $\mathrm{COD}_{\mathrm{Cr}}$ removal (Figure 2a) showed a decreasing trend after a rapid increase. The inflection points of divalent ions $\left(\mathrm{Mg}^{2+}, \mathrm{Ca}^{2+}\right.$ and $\left.\mathrm{Fe}^{2+}\right)$ for the $\mathrm{COD}_{\mathrm{Cr}}$ removal of the L-MWFs were generated earlier than the trivalent ions $\left(\mathrm{Al}^{3+}\right.$ and $\mathrm{Fe}^{3+}$ ). The optimum dosage of the divalent ions (i.e., $\mathrm{Mg}^{2+}$, $\mathrm{Ca}^{2+}$ and $\mathrm{Fe}^{2+}$ ) was $0.06 \mathrm{~mol} / \mathrm{L}$, and the $\mathrm{COD}_{\mathrm{Cr}}$ removal was $46.44 \%, 51.88 \%$ and $53.91 \%$, respectively; relatively, the dosage of trivalent ions (i.e., $\mathrm{Al}^{3+}$ and $\mathrm{Fe}^{3+}$ ) was $0.08 \mathrm{~mol} / \mathrm{L}$, and the highest $\mathrm{COD}_{\mathrm{Cr}}$ removal was $58.06 \%$ and $59.88 \%$, respectively. Under the same concentration, the removal of trivalent ions for the $\mathrm{COD}_{\mathrm{Cr}}$ of $\mathrm{L}-\mathrm{MWF}$ were superior to that of divalent ions. Compared with the other four ions, the removal of $\mathrm{Al}^{3+}$ for $\mathrm{COD}_{\mathrm{Cr}}$ was the most advantageous.

The ion strength was an index for measuring the common effect of all ions in solution, which was directly related to the concentration and type of ions [26]. The original L-MWFs contained the fixed ion strength, so the change in ion strength before and after adding the inorganic demulsifier was inspected by differential ion strength (Equations (2)-(5)). In order to eliminate the interference of ion concentration, the difference of different types of metal ions for the L-MWFs' demulsification was distinguished, and the computing mode of normalized ion strength was as shown in Equation (6):

$$
\begin{gathered}
\Delta I_{a b s}=I_{e}-I_{o} ; I_{o}=\frac{1}{2} \sum_{k=1}^{m} c_{k} z_{k}^{2} \\
\Delta I_{a b s}=\frac{1}{2}\left(\sum_{i=1}^{n} c_{i} z_{i}^{2}+\sum_{k=1}^{m} c_{k}^{*} z_{k}^{2}\right)-\sum_{k=1}^{m} c_{k} z_{k}^{2} \cong \frac{1}{2}\left(\sum_{i=1}^{n} c_{i} z_{i}^{2}\right) \\
c_{k}=\frac{m_{k}}{V_{o}} ; c_{k}^{*}=\frac{m_{k}}{V_{o}+V_{a d d}}, V_{o}+V_{a d d}=V_{e} \\
V_{a d d} \ll V_{o} \rightarrow V_{o}=V_{e} \rightarrow c_{k}^{*} \cong c_{k}
\end{gathered}
$$

where,

$\Delta I_{a b s}:$ Differential ion strength $(\mathrm{mol} / \mathrm{L})$;

$I_{e}$ : Ion strength in the L-MWFs after dosing $(\mathrm{mol} / \mathrm{L})$;

$I_{o}$ : Initial ion strength in L-MWFs $(\mathrm{mol} / \mathrm{L})$;

$c_{i}$ : Dosing concentration of $\mathrm{i}$ ion in demulsifier $(\mathrm{mol} / \mathrm{L})$;

$c_{k}$ : Concentration of $\mathrm{K}$ ion in L-MWFs (mol/L);

$c_{k}^{*}$; Concentration of K ion in L-MWFs after being added with demulsifier $(\mathrm{mol} / \mathrm{L})$;

$z_{k}$ : Charge number of K ion in L-MWFs;

$z_{i}$ : Charge number of $\mathrm{i}$ ion in demulsifier;

$m_{k}$ : Substance number of K ion in L-MWFs (mol);

$V_{o}$ : Volume of L-MWFs (L);

$V_{\text {add }}$ : Volume of demulsifier added (L);

$V_{e}$ : Total volume of L-MWFs after being added with demulsifier (L).

The normalized differential ion strength is calculated as:

$$
\Delta I_{\text {nor }}=1 / 2 \sum_{\substack{i=1, \\ \text { cation }}}^{n} \frac{c_{i} z_{i}^{2}}{c_{i}}+1 / 2 \sum_{\substack{i, j_{i=1} \\ \text { anion }}}^{m} \frac{c_{j i} z_{1}^{2}}{c_{i}}
$$

where,

$c_{j i}$ : Concentration of anion corresponding to i cation in demulsifier (mol/L).

As seen from Table 2 [27], the ion strength played a significant promotion role in the degradation of $\mathrm{COD}_{\mathrm{Cr}}$. In addition, the solubility of other salts in solution was increased, and the high normalized ion strength system may also promote the rupture of interfacial film of oil drop. The normalized ion strength of $\mathrm{Al}^{3+}$ and $\mathrm{Fe}^{3+}$ was 6.00 and 7.00, respectively, which was higher than that of the other ions, so the degradation effect on $\mathrm{COD}_{\mathrm{Cr}}$ 
was obvious. On the other hand, the organic matter removal effect of $\mathrm{Ca}^{2+}$ was better than that of $\mathrm{Mg}^{2+}$ under the same normalized ion strength because the hydration radius ratio of $\mathrm{Ca}^{2+}$ was smaller than that of $\mathrm{Mg}^{2+}$ (Table 2). $\mathrm{Ca}^{2+}$ was easy to absorb and neutralize with anion oil drop, and it permeated and adhered to the interface of the emulsion drop [28] so as to destroy the stability of the interfacial film of oil and water, so it was beneficial for the demulsification of L-MWFs.

Table 2. Ion radius of metal cation and normalized ion strength in experiment [27].

\begin{tabular}{cccccc}
\hline Metal Cation & $\mathbf{A l}^{3+}$ & $\mathbf{F e}^{3+}$ & $\mathbf{F e}^{2+}$ & $\mathbf{M g}^{2+}$ & $\mathbf{C a}^{2+}$ \\
\hline Ionic radius (pm) & 53.50 & 64.00 & 75.00 & 72.00 & 100.00 \\
Hydrated ion radius (nm) & 0.48 & 0.48 & 0.43 & 0.43 & 0.41 \\
Normalized ionic strength & 6.00 & 7.00 & 4.00 & 3.00 & 3.00 \\
\hline
\end{tabular}

Note: The data on the ionic radius and hydrated ion radius were obtained from reference; the normalized ionic strength was calculated according to Equation (6). Reproduced with permission of reference [27], copyright of 2012 Elsevier.

Under the same ion concentration, the effect of different types of ions on the $\mathrm{SV}_{30}$ ratio after demulsification was as shown in Figure 2b. Except for the $\mathrm{SV}_{30}$ ratio of $\mathrm{Fe}^{3+}$ presenting a volcanic curve, the $\mathrm{SV}_{30}$ ratio of the other four ions were increased linearly with the ion concentration. The electronegativity of the demulsification system was neutralized by the increase in ion concentration so that the system was out of balance to generate the separated effect. At the same time, it could be seen that the sludge quantity generated by $\mathrm{Fe}^{2+}$ and $\mathrm{Ca}^{2+}$ was less and that generated by $\mathrm{Fe}^{3+}$ was the most.

The transmittance of the supernatant after the demulsification was as shown in Figure 2c. The transmittance of the supernatants of $\mathrm{Ca}^{2+}$ and $\mathrm{Mg}^{2+}$ were less than $10.00 \%$, so they showed a turbid effluent, which may be caused by tiny hydroxide particulate matter formed by $\mathrm{Ca}^{2+}$ and $\mathrm{Mg}^{2+}$. Under $0.08 \mathrm{~mol} / \mathrm{L}$ and $0.06 \mathrm{~mol} / \mathrm{L}$, the optimum transmittances of $\mathrm{Fe}^{3+}$ and $\mathrm{Fe}^{2+}$ were $34.02 \%$ and $27.70 \%$, respectively. On the contrary, when the dosage of $\mathrm{Al}^{3+}$ was $0.12 \mathrm{~mol} / \mathrm{L}$, the supernatant was the clearest, and the highest transmittance was $68.20 \%$. The reason for the clearer $\mathrm{Al}^{3+}$ supernatant may be that it had a better absorption-gathering-netting effect when the $\mathrm{pH}$ of $\mathrm{Al}^{3+}$ was 8.50 in the form of $\mathrm{Al}(\mathrm{OH})_{3}$ and $\mathrm{Al}(\mathrm{OH})_{4}{ }^{-}$complex ions [29]. The existence of the metal cation played a decisive role in the transmittance of the supernatant after demulsification.

The $\mathrm{COD}_{\mathrm{Cr}} / \mathrm{SV}_{30}$ ratio (Equation (7)) was introduced to the L-MWFs for the first time, so as to further evaluate the relationship between removal of organic pollutants and yield of secondary sludge. It is calculated as follows:

$$
\mathrm{COD}_{\mathrm{Cr}} / \mathrm{SV}_{30} \text {-ratio }=\frac{\mathrm{COD}_{0}-\mathrm{COD}_{i}}{\mathrm{SV}_{30 \text {-ratio }}} \times 100 \%
$$

where,

$\mathrm{COD}_{0}$ : Initial $\mathrm{COD}_{\mathrm{Cr}}$ of L-MWFs $(\mathrm{mg} / \mathrm{mL}) ;$

$C O D_{i}: \mathrm{COD}_{\mathrm{Cr}}$ of supernatant after demulsification experiment for the first time $(\mathrm{mg} / \mathrm{mL})$.

The concept or the physical significance of the $\mathrm{COD}_{\mathrm{Cr}} / \mathrm{SV}_{30}$ ratio can be interpreted as the mass of $\mathrm{COD}_{\mathrm{Cr}}$ that can be removed by $1 \mathrm{~mL}$ of the sludge, which was settled for $30 \mathrm{~min}$ : in other words, the absolute contribution rate of sludge product for the $\mathrm{COD}_{\mathrm{Cr}}$ removal. Additionally, because the dosing demulsification inevitably generated the flocculent precipitation and the dehydration and compression process for the nascent sludge (by which to generate the final sludge, which was of greater concern from the engineering point of view) would be reported in the follow-up article in details, the generation of the nascent sludge was represented by the $\mathrm{SV}_{30}$ ratio in the economy aspect. As the concentration of the $\mathrm{COD}_{\mathrm{Cr}}$ with the same mass was removed, the larger the $\mathrm{COD}_{\mathrm{Cr}} / \mathrm{SV}_{30}$ ratio was, the smaller the yield of secondary sludge was and the better the effect of the demulsification was. If the minimum $\mathrm{SV}_{30}$ ratio and maximum $\mathrm{COD}_{\mathrm{Cr}}$ removal were met at the same time, not only was the reduction of wastewater treatment was realized but the environmental 
protection cost of the workshop was also reduced. The $\mathrm{COD}_{\mathrm{Cr}} / \mathrm{SV}_{30}$ ratio index had double significance of environmental protection and economy.

As a whole, the sequence (Figure $2 \mathrm{~d}$ ) of the $\mathrm{COD}_{\mathrm{Cr}} / \mathrm{SV}_{30}$ ratio of five metal ions was $\mathrm{Fe}^{2+}>\mathrm{Ca}^{2+}>\mathrm{Al}^{3+}>\mathrm{Mg}^{2+} \approx \mathrm{Fe}^{3+}$, and the $\mathrm{COD}_{\mathrm{Cr}} / \mathrm{SV}_{30}$ ratio versus the ion concentration was presented into two stages, which were as follows. (i) Before the ion concentration was $0.08 \mathrm{~mol} / \mathrm{L}$, the $\mathrm{COD}_{\mathrm{Cr}} / \mathrm{SV}_{30}$ ratios of all metal ions for L-MWFs were obviously decreased with the increase in concentration. When the dosage was $0.02 \mathrm{~mol} / \mathrm{L}$, all metal ions reached up to the highest $\mathrm{COD}_{\mathrm{Cr}} / \mathrm{SV}_{30}$ ratio (where $\mathrm{Fe}^{2+}$ had the highest $\mathrm{COD}_{\mathrm{Cr}} / \mathrm{SV}_{30}$ ratio, $189.71 \mathrm{mg} / \mathrm{mL}$ ), and the effluent transmission and $\mathrm{COD}_{\mathrm{Cr}}$ removal showed a trend of synchronous rise, which showed that the L-MWFs' oil pollutants were increased gradually with the increase in the metal ion concentration at this stage. (ii) After the ion concentration exceeded $0.08 \mathrm{~mol} / \mathrm{L}$, the $\mathrm{COD}_{\mathrm{Cr}} / \mathrm{SV}_{30}$ ratio gradually became stable, and the transmittance of $\mathrm{Fe}^{2+}$ and $\mathrm{Fe}^{3+}$ of the ferric salt experimental group was reduced gradually, which showed that the iron ion residue would affect the effluent transmittance. Therefore, the upper limit of iron ions should be controlled in the use process of ferric salt to prevent effluent turbidity. Specifically, $\mathrm{Al}^{3+}$ had a good effect on the $\mathrm{COD}_{\mathrm{Cr}}$ removal and the effluent transmittance index of L-MWFs. $\mathrm{Fe}^{3+}$ had the maximum ion strength, and $\mathrm{Fe}^{2+}$ had the minimum $\mathrm{SV}_{30}$ ratio and optimum $\mathrm{COD}_{\mathrm{Cr}} / \mathrm{SV}_{30}$ ratio, which played a role in concentrating the oil pollutants in large proportion. Therefore, these three metal ions were selected as the objects of metallic combination demulsification.

\subsection{Effect of Bi-Metal Ion Combination on L-MWFs Demulsification}

When the total ion concentration was $0.08 \mathrm{~mol} / \mathrm{L}$, the reaction $\mathrm{pH}$ was 8.50 , the stirring time was $18 \mathrm{~min}$ and the temperature was $283 \mathrm{~K}$. Three metal ions including $\mathrm{Fe}^{3+}, \mathrm{Fe}^{2+}$ and $\mathrm{Al}^{3+}$ were selected for the synergistic demulsification of bi-metal $C_{3}^{2}$ of L-MWFs, and the results are as shown in Figure 3.
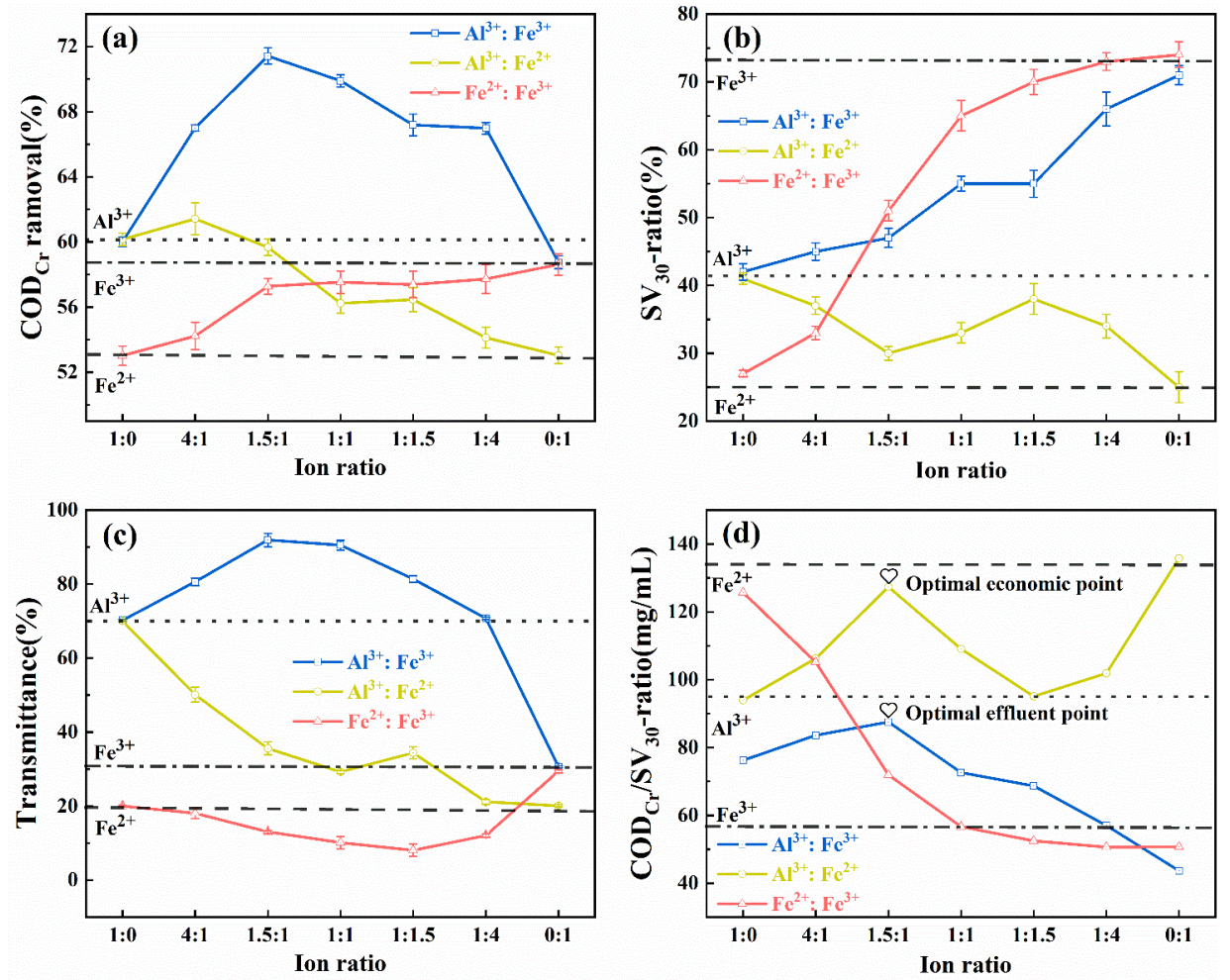

Figure 3. Demulsification effect of bi-metal ion combination on L-MWFs (total ion concentration was $0.08 \mathrm{~mol} / \mathrm{L}$ ): (a) $\mathrm{COD}_{\mathrm{Cr}}$ removal, (b) $\mathrm{SV}_{30}$ ratio, (c) transmittance, (d) $\mathrm{COD}_{\mathrm{Cr}} / \mathrm{SV}_{30}$ ratio. The process conditions of the above experiments were as follows: temperature was $283 \mathrm{~K}$ (Room temperature), total ion concentration was $0.08 \mathrm{~mol} / \mathrm{L}$, $\mathrm{pH}$ was 8.50 (Initial $\mathrm{pH}$ of L-MWFs), stirring time was $18 \mathrm{~min}$. 


\subsubsection{Effect of Bi-Metal Ion Combination on $\mathrm{COD}_{\mathrm{Cr}}$ Removal}

As shown in Figure 3a, in contrast with the dotted line in figure, it could be seen that the combination of $\mathrm{Al}^{3+}$ and $\mathrm{Fe}^{3+}$ had an obviously synergistic effect. The combination of $\mathrm{Al}^{3+}$ and $\mathrm{Fe}^{3+}$ in arbitrary proportion was superior to the effect of the mono-ion, especially when $\mathrm{Al}^{3+}: \mathrm{Fe}^{3+}=1.5: 1$, and the $\mathrm{COD}_{\mathrm{Cr}}$ removal was up to $71.40 \%$, which was increased by $11.52 \%$ and $13.34 \%$, respectively, compared with $0.08 \mathrm{~mol} / \mathrm{L}$ single $\mathrm{Al}^{3+}$ or $\mathrm{Fe}^{3+}$. The synergistic effect did not occur when $\mathrm{Fe}^{3+}$ was combined with $\mathrm{Fe}^{2+}$. When $\mathrm{Al}^{3+}: \mathrm{Fe}^{2+}=4: 1$, $\mathrm{COD}_{\mathrm{Cr}}$ removal was increased to $61.43 \%$, which was only increased by $1.42 \%$ compared with single $\mathrm{Al}^{3+}$, and the synergistic effect almost did not occur. With the increase in the proportion of $\mathrm{Fe}^{2+}$, the $\mathrm{COD}_{\mathrm{Cr}}$ removal was reduced gradually because the smaller the $\mathrm{Al}^{3+}$ content was, the worse the flocculation effect was.

The combination of $\mathrm{Al}^{3+}$ and $\mathrm{Fe}^{3+}$ generated an obviously synergistic effect. Its reasons could be that (i) compared with other divalent metal ions, $\mathrm{Fe}^{3+}$ with higher normalized ion strength obviously increased the ion strength of solution system and had a stronger absorption and neutralization reaction with the electronegative impurity particles, and it was easier to destroy the stability of the oil-water interfacial film; (ii) at the same time, under the higher ion strength, multiple multi-nuclear hydroxy complexes such as $\mathrm{Al}_{6}(\mathrm{OH})_{15}{ }^{3+}$ and $\mathrm{Al}_{7}(\mathrm{OH})_{17}{ }^{4+}$ or colloidal precipitate $\mathrm{Al}(\mathrm{OH})_{3}$ were generated by the fast hydrolysis of $\mathrm{Al}^{3+}$ [30]. These complexes or colloidal precipitates swept or net the impurity particles having been destabilized in the precipitation system for co-precipitation so as to have an excellent flocculation demulsification effect.

\subsubsection{Effect of Bi-Metal Ion Combination on $\mathrm{SV}_{30}$-Ratio}

As shown in Figure $3 b$, the combination of three metal ions did not show the obviously synergistic effect but showed a certain rule. The $\mathrm{SV}_{30}$ ratio was increased gradually with the increase in the proportion of $\mathrm{Fe}^{3+}$ in combination, but it did not exceed $85.00 \%$ of that of single $\mathrm{Fe}^{3+}$ under the same ion concentration. In the combination of $\mathrm{Al}^{3+}$ and $\mathrm{Fe}^{2+}$, when $\mathrm{Al}^{3+}: \mathrm{Fe}^{2+}=1.5: 1$, the $\mathrm{SV}_{30}$ ratio was lowered to $30.00 \%$, but with the increase in the content of $\mathrm{Fe}^{2+}$, the $\mathrm{SV}_{30}$ ratio curve showed a decreasing trend after an increase. It could be seen that the volume of sludge would be reduced with the increase in the proportion of $\mathrm{Fe}^{2+}$ in combination, which may be related to the diameter of flocculation with higher $\mathrm{Fe}^{2+}$ and water content of flocculation with lower $\mathrm{Fe}^{2+}$. On the contrary, the volume of sludge would be increased by $\mathrm{Fe}^{3+}$, and the slow sedimentation of $\mathrm{Fe}^{3+}$ may be related to the small diameter of flocculation. However, the effect of $\mathrm{Al}^{3+}$ on the yield of sludge was between $\mathrm{Fe}^{3+}$ and $\mathrm{Fe}^{2+}$.

\subsubsection{Effect of Bi-Metal Ion Combination on Effluent Transmittance}

As shown in Figure 3c, the combination of $\mathrm{Al}^{3+}+\mathrm{Fe}^{2+}$ and $\mathrm{Fe}^{2+}+\mathrm{Fe}^{3+}$ did not have a synergistic effect. However, $\mathrm{Fe}^{2+}+\mathrm{Fe}^{3+}$ showed an antagonistic effect, and the antagonistic effect of $\mathrm{Fe}^{2+}: \mathrm{Fe}^{3+}=1: 1.5$ was especially significant: the transmittance was only $8.06 \%$, which was only lower than $15.50 \%$ of single $\mathrm{Fe}^{2+}$ and $34.02 \%$ of single $\mathrm{Fe}^{3+}$. The supernatant may be turbid due to the residue of $\mathrm{Fe}^{3+}$ and $\mathrm{Fe}^{2+}$. In addition, $\mathrm{Al}^{3+}+\mathrm{Fe}^{3+}$ had an obviously synergistic effect after combination, and the transmittance of supernatant after demulsification of $\mathrm{Al}^{3+}+\mathrm{Fe}^{3+}$ in any proportion was superior to that of $\mathrm{Al}^{3+}$ or $\mathrm{Fe}^{3+}$. Especially when $\mathrm{Al}^{3+}: \mathrm{Fe}^{3+}=1.5: 1$, the transmittance of the supernatant increased up to $91.90 \%$. Coincidentally, the condition was identical to the highest $\mathrm{COD}_{\mathrm{Cr}}$ removal in Figure 2a. The high transmittance may be caused by the existence of $\mathrm{Al}^{3+}$ in the form of $\mathrm{Al}(\mathrm{OH})_{3}$ and $\mathrm{Al}(\mathrm{OH})_{4}{ }^{-}$when $\mathrm{pH}$ was 8.50. The absorption-sweeping-netting effect of $\mathrm{Al}^{3+}$ interacted with the neutralization effect of the strong current of $\mathrm{Fe}^{3+}$. The anionic emulsifier and oil drop in the wastewater were easy to be transferred to the precipitation.

\subsubsection{Effect of Bi-Metal Ion Combination on $\mathrm{COD}_{\mathrm{Cr}} / \mathrm{SV}_{30}$-Ratio}

As shown in Figure $3 \mathrm{~d}$, because the transmittance and the $\mathrm{COD}_{\mathrm{Cr}}$ removal of $\mathrm{Fe}^{2+}: \mathrm{Fe}^{3+}=1: 0$ were only $20.03 \%$ and $53.02 \%$, respectively, the peak of the combination 
of $\mathrm{Fe}^{2+}$ and $\mathrm{Fe}^{3+}$ was not the optimal option of demulsification. It could be seen that the demulsification combinations $\mathrm{Al}^{3+}: \mathrm{Fe}^{2+}=1.5: 1$ and $\mathrm{Al}^{3+}: \mathrm{Fe}^{3+}=1.5: 1$ were remarkable, as shown in Figure 3abc. In the $\mathrm{Al}^{3+}: \mathrm{Fe}^{2+}=1.5: 1$ combination, $127.31 \mathrm{mg} \mathrm{COD}_{\mathrm{Cr}}$ could be removed by $1 \mathrm{~mL}$ sludge, but the $\mathrm{COD}_{\mathrm{Cr}}$ removal was only $59.67 \%$, and the transmittance was only $35.60 \%$. Meanwhile, at the proportion of $\mathrm{Al}^{3+}: \mathrm{Fe}^{3+}=1.5: 1$, the transmittance of the supernatant of L-MWFs was $91.90 \%$, and the $\mathrm{COD}_{\mathrm{Cr}}$ removal was $71.43 \%$, but the $\mathrm{SV}_{30}$ ratio was $47.00 \%$, and the $\mathrm{COD}_{\mathrm{Cr}} / \mathrm{SV}_{30}$ ratio was only $87.53 \mathrm{mg} / \mathrm{mL}$.

So, the option of $\mathrm{Al}^{3+}: \mathrm{Fe}^{2+}=1.5: 1$ could reduce the yield of sludge, but the $\mathrm{COD}_{\mathrm{Cr}}$ removal and transmittance of L-MWFs were low; on the contrary, the option of $\mathrm{Al}^{3+}: \mathrm{Fe}^{3+}=1.5: 1$ could increase the $\mathrm{COD}_{\mathrm{Cr}}$ removal and transmittance of effluent of L-MWFs but would generate more sludge. Their common point was that the content of $\mathrm{Al}^{3+}$ was $60.00 \%$, indicating that $\mathrm{Al}^{3+}$ played an overall effect on the demulsification, and it was deployed properly through the addition of ferric salt at different valence states according to the engineering need, so as to meet the requirement for effluent concentration or the requirement for sludge reduction, respectively.

\subsection{Example for the Optimization of Operating Condition and Economy Evaluation}

Taking the formulation of $\mathrm{Al}^{3+}: \mathrm{Fe}^{3+}=1.5: 1$ as an example, the optimization process was carried out by a single factor experiment which was designed based on the total ion concentration of the demulsifier, the reaction $\mathrm{pH}$, the stirring time and the temperature as factors, and the effect as well as the optimum parameters which were scrutinized by taking $\mathrm{COD} \mathrm{Cr}_{\mathrm{r}}$ removal, $\mathrm{SV}_{30}$ ratio and $\mathrm{COD}_{\mathrm{Cr}} / \mathrm{SV}_{30}$ ratio as indices was as shown in Figure 4:
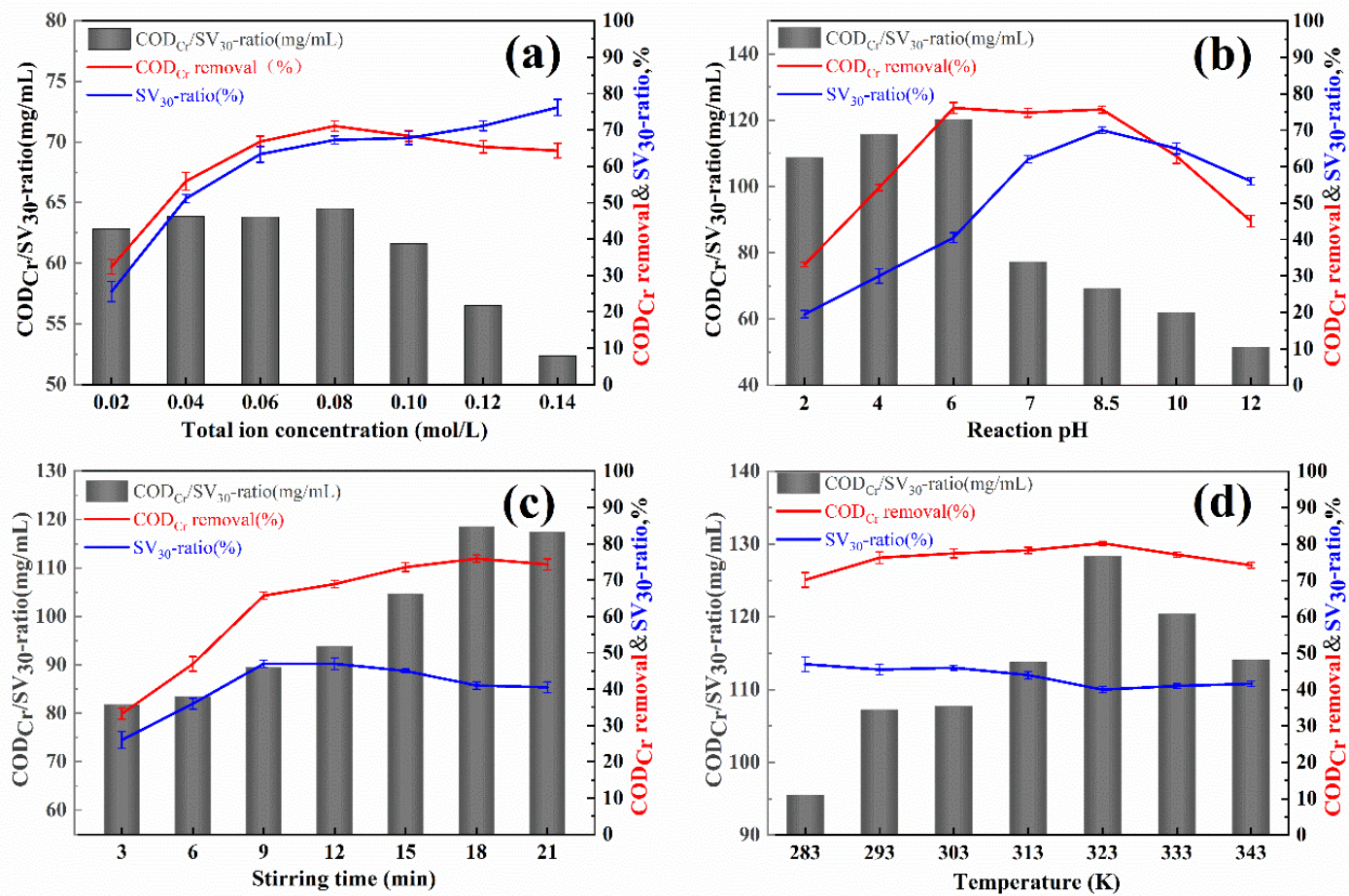

Figure 4. Single factor experiment of combined demulsification of $\mathrm{Al}^{3+}: \mathrm{Fe}^{3+}=1 \cdot 5: 1$. (a) Influence of total ion concentration of demulsifier on L-MWFs demulsification, process conditions: $\mathrm{pH}$ was 8.50, stirring time was 18 min, temperature was $283 \mathrm{~K}$; (b) effect of reaction $\mathrm{pH}$ on L-MWFs demulsification, process conditions: total ion concentration was $0.08 \mathrm{~mol} / \mathrm{L}$, stirring time was $18 \mathrm{~min}$, temperature was $283 \mathrm{~K}$; (c) effect of stirring time on L-MWFs demulsification, process conditions: total ion concentration was $0.08 \mathrm{~mol} / \mathrm{L}$, pH was 6.00, temperature was $283 \mathrm{~K}$; (d) effect of temperature on L-MWFs demulsification, process conditions: total ion concentration was $0.08 \mathrm{~mol} / \mathrm{L}$, $\mathrm{pH}$ was 6.00 , stirring time was $18 \mathrm{~min}$.

As shown in Figure $4 a$, with the increase in the dosing concentration of the demulsifier, the $\mathrm{COD}_{\mathrm{Cr}}$ removal was reduced after being increased. When the total ion concentration of the demulsifier was $0.08 \mathrm{~mol} / \mathrm{L}$, the highest $\mathrm{COD}_{\mathrm{Cr}}$ removal was $71.05 \%$, and it was 
increased by $38.65 \%$ compared with that when the total ion concentration was $0.02 \mathrm{~mol} / \mathrm{L}$ because the ion strength was increased with the increase in the dosing concentration, which promoted the degradation of $\mathrm{COD}_{\mathrm{Cr}}$. However, the reason for the non-ideal effect due to excessive dosing may be that the repeated stabilization appeared through excessive ions with the same number added. On the other hand, the $\mathrm{SV}_{30}$ ratio was increased gradually from $33.00 \%$ of $0.02 \mathrm{~mol} / \mathrm{L}$ to $78.60 \%$ of $0.14 \mathrm{~mol} / \mathrm{L}$ with the increase in the ion concentration. In combination with the bar graph of the $\mathrm{COD}_{\mathrm{Cr}} / \mathrm{SV}_{30}$ ratio, it can be seen that the demulsification effect and the economy were optimum when the ion concentration was $0.08 \mathrm{~mol} / \mathrm{L}$.

As shown in Figure 4b, the effect of pH on L-MWFs' demulsification effect was huge, mainly because the $\mathrm{pH}$ value had a direct influence on the existence form of the metal cations. The aluminum salt and ferric salt were not simple $\mathrm{Al}^{3+}$ or $\mathrm{Fe}^{3+}$ after ionization in water but had the hydrolytic polymerization and other reactions. The morphology of hydrolytic polymerization formed by $\mathrm{Al}^{3+}$ and $\mathrm{Fe}^{3+}$ had the effects of absorption charge neutralization and bridging, among others, on colloidal particles and oil droplets, so it was especially critical.

With the increase in $\mathrm{pH}$, the $\mathrm{COD}_{\mathrm{Cr}}$ removal was firstly increased to keep stable at 6.00-8.50 and then decreased. When $\mathrm{pH}$ was $2.00-4.00$, the $\mathrm{COD}_{\mathrm{Cr}}$ removal was lower than $54.23 \%$ because the morphology of the metal cations mainly included $\mathrm{Al}\left(\mathrm{H}_{2} \mathrm{O}\right)_{\mathrm{n}}{ }^{3+}$ and $\mathrm{Fe}\left(\mathrm{H}_{2} \mathrm{O}\right)_{6}{ }^{3+}[15]$ and other monomer forms, the degree of polymerization was low and the flocculation ability was poor. The $\mathrm{SV}_{30}$ ratio was lower than $30.00 \%$, but the supernatant was turbid due to the poor demulsification effect. When $\mathrm{pH}$ was 6.00-8.50, the supernatant was clear light orange, and the $\mathrm{COD}_{\mathrm{Cr}}$ removal was up to $76.13 \%$. The positively charged iron carbonyl ion and the morphology of the multi-nuclear polymerization were formed by $\mathrm{Fe}^{3+}$ and have a good absorption charge neutralization and double electrode layer compression effects. In addition, $\mathrm{Al}^{3+}$ would gradually form partial $\mathrm{Al}(\mathrm{OH})_{3}$ and the multi-nuclear polymers, such as $\mathrm{Al}_{6}(\mathrm{OH})_{15}{ }^{3+}, \mathrm{Al}_{7}(\mathrm{OH})_{17}{ }^{4+}, \mathrm{Al}_{13}(\mathrm{OH})_{34}{ }^{5+}$ and other morphologies, and the degree of polymerization were increased gradually. The high polymer played absorption charge neutralization, bridging and netting and sweeping roles at this stage, and the flocculation and demulsification effects were good. The $S_{30}$ ratio curve showed a trend of obvious rise, which may be related to the poor settling performance of the polymers with high degrees of polymerization. Thereafter, when $\mathrm{pH}$ was $10.00-12.00$, the supernatant gradually became red and finally became deep red at $\mathrm{pH} 12.00$ (Figure S2). The change in color of the supernatant and the decrease in the degradation ability of $\mathrm{COD}_{\mathrm{Cr}}$ were created by undissolvable $\mathrm{Al}(\mathrm{OH})_{3}$ and $\mathrm{Fe}(\mathrm{OH})_{3}$ sediment and negatively charged complex $\mathrm{Al}(\mathrm{OH})_{4}{ }^{-}$and $\mathrm{Al}_{8}(\mathrm{OH})_{26}{ }^{2-}$ anions [15], and it was difficult to remove the impurity particle in water through the adhesion effect. Due to the increased ease of settling in hydroxide, the $\mathrm{SV}_{30}$ ratio showed a decreasing trend.

The $\mathrm{COD}_{\mathrm{Cr}} / \mathrm{SV}_{30}$ ratio was highly acidic, and the maximum value was $120.30 \mathrm{mg} / \mathrm{mL}$ when $\mathrm{pH}$ was 6.00. It could be seen that the optimum effluent property and demulsification economy were owned when $\mathrm{pH}$ was 6.00 , so the follow-up single factor experiment was conducted with the total ion concentration of $0.08 \mathrm{~mol} / \mathrm{L}$ and $\mathrm{pH}$ of 6.00 .

As shown in Figure $4 c, C_{C r}$ removal was increased gradually with the extension of stirring time, and it was $75.92 \%$ at $18 \mathrm{~min}$. The extension of stirring time could promote more sufficient contact time between the $\mathrm{COD}_{\mathrm{Cr}}$ and the flocculation due to the removal of oil droplets and other impurity particles and increased the efficiency of carrying impurity of flocculation. The $\mathrm{SV}_{30}$ ratio curve showed the trend of slow decrease after transient increase, and the yield of sludge was $40.50 \%$ at 21 min because the flocculation could absorb more impurity particles. The diameter was also increased, which was beneficial for sedimentation. The $\mathrm{COD}_{\mathrm{Cr}} / \mathrm{SV}_{30}$ ratio was increased with the increase of stirring time, and the maximum value was $118.52 \mathrm{mg} / \mathrm{mL}$ at $18 \mathrm{~min}$. Therefore, the follow-up single factor experiment was selected when the total ion concentration was $0.08 \mathrm{~mol} / \mathrm{L}$, pH was 6.00 and the stirring time was $18 \mathrm{~min}$. 
The effect of temperature (Figure $4 \mathrm{~d}$ ) on $\mathrm{COD}_{\mathrm{Cr}}$ removal and the $\mathrm{SV}_{30}$ ratio was less. The temperature rose from $283 \mathrm{~K}$ to $323 \mathrm{~K}$, the $\mathrm{COD}_{\mathrm{Cr}}$ removal was increased by $10.06 \%$ and the $\mathrm{SV}_{30}$ ratio was decreased by $7.00 \%$. The molecular heat motion in liquid was acute, and the stable state was difficult to maintain at high temperatures [31]. In addition, the hydrolysis was an endothermic reaction. The demulsifier, oil droplets and other impurity particles made contact in a more sufficient way with the increase in temperature so as to promote the generation of flocculation and degradation of $\mathrm{COD}_{\mathrm{Cr}}$. When the temperature was $323 \mathrm{~K}$, the maximum value of the $\mathrm{COD}_{\mathrm{Cr}} / \mathrm{SV}_{30}$ ratio was $128.33 \mathrm{mg} / \mathrm{mL}$, so it owned the maximum $\mathrm{COD}_{\mathrm{Cr}}$ removal, the minimum quantity of sludge by-product and showed good demulsification effects and economy.

Based on the optimum conditions obtained by the single factor experiment, the economy evaluation in the operating cost was carried out under the total ion concentration of $0.08 \mathrm{~mol} / \mathrm{L}$, $\mathrm{pH}$ of 6.00 , a stirring time of $18 \mathrm{~min}$ and a temperature of $323 \mathrm{~K}$. The $\mathrm{COD}_{\mathrm{Cr}}$ removal was $80.21 \%$, the $\mathrm{SV}_{30}$ ratio was $40.00 \%$, the transmittance was $95.20 \%$ and the $\mathrm{COD}_{\mathrm{Cr}} / \mathrm{SV}_{30}$ ratio was $128.33 \mathrm{mg} / \mathrm{mL}$. In addition, in spite of the depreciation of the equipment, the subsequent treatment for the liquid supernatant, as well as the operating labor cost, only the main agents (i.e., $\mathrm{AlCl}_{3}, \mathrm{FeCl}_{3}, \mathrm{PAM}$, etc.), sludge and powder cost of $1 \mathrm{~m}^{3}$ of L-MWFs are roughly calculated in Table 3:

Table 3. Direct operating cost of $1 \mathrm{~m}^{3}$ of L-MWFs.

\begin{tabular}{|c|c|c|c|c|}
\hline \multirow{2}{*}{$\begin{array}{l}\text { Direct Operating Cost } \\
\qquad\left(\mathbf{1 ~ m}^{3}\right)\end{array}$} & \multicolumn{3}{|c|}{$\begin{array}{l}\text { Bi-Metal Ion Combination Demulsification } \\
\text { Treatment Carried out in this Study }\end{array}$} & \multirow[t]{2}{*}{$\begin{array}{c}\text { Output } \\
\text { Treatment }\end{array}$} \\
\hline & Agents ${ }^{1}$ & Sludge Disposal $^{2}$ & Power Charge ${ }^{3}$ & \\
\hline $\begin{array}{l}\text { Cost (USD) } \\
\text { Total (USD) }\end{array}$ & $\leq 14.26$ & $\begin{array}{l}\leq 37.08 \\
\operatorname{Max}=51.50\end{array}$ & $\approx 0.16$ & 463.50 \\
\hline
\end{tabular}

Cut down (USD) 412.00

Note: ${ }^{1} \mathrm{AlCl}_{3}$ was $309 \mathrm{USD} / \mathrm{t}, \mathrm{FeCl}_{3}$ was $309 \mathrm{USD} / \mathrm{t}$, PAM was $1545 \mathrm{USD} / \mathrm{t}$, industrial sulfuric acid was $123.6 \mathrm{USD} / \mathrm{t}$ 2 The charge for the sludge was the same as L-MWFs, $463.5 \mathrm{USD} / \mathrm{m}^{3}{ }^{3}$ The power charge calculated according to a normal chemical reactor (which can be bought in any chemical equipment market) with the reaction time, reaction volume and installed power of $18 \mathrm{~min}, 330 \mathrm{~L}$ and $3 \mathrm{KW}$, respectively. The electricity price for industrial uses was $0.16 \mathrm{USD} / \mathrm{KWh}[32,33] .{ }^{4}$ The cost of output of L-MWFs referred to the average price of China's environmental protection market [32]. The exchange rate between RMB and USD: 1 RMB $=0.1545$ USD.

In any case, the operating cost of the demulsification treatment process for L-MWFs occupied nearly $10.00 \%$ of the current output treatment. Obviously, the cut down was significant, which lowered down the operating cost for the related processing and manufacturing workshops throughout China. Referred to the calculation method of [32,33], in comparison with membrane demulsification and thermal demulsification, the bi-metal ion combination demulsification treatment proposed in this study exerted excellent economic efficiency in equipment investments and daily operating costs (Table 4).

Table 4. Economic analysis of different L-MWF disposal strategies for a typical medium-scale full-set of stainless-steel auto parts processing workshop ${ }^{1}(200 \mathrm{t} / \mathrm{y})$.

\begin{tabular}{|c|c|c|c|c|}
\hline \multicolumn{2}{|c|}{ Cost Composition (USD) } & BCD $^{2}$ (This Study) & $\mathrm{MD}^{3}$ & $\mathrm{TD}^{4}$ \\
\hline \multirow{2}{*}{$\begin{array}{c}\text { Equipment } \\
\text { Investment }\end{array}$} & Disposable investment & 3098.00 & $23,235.00$ & 4647.00 \\
\hline & Annual average investment & 309.80 & 2323.50 & 464.70 \\
\hline Direct operating cost ${ }^{6}$ & Annually & $10,300.00$ & $72,100.00$ & $27,450.00$ \\
\hline Maintenance charges ${ }^{7}$ & Annually & 102.23 & 766.76 & 153.35 \\
\hline \multicolumn{2}{|c|}{ Annual cost } & $10,712.03$ & $75,190.25$ & $28,068.05$ \\
\hline \multicolumn{2}{|c|}{ Total cost for 10 years } & $110,218.34$ & $775,137.55$ & $285,327.51$ \\
\hline
\end{tabular}

Note: ${ }^{1}$ Workshop equipped with 200 -axis machine tools with metalworking, cutting, cleaning and other complete functions; ${ }^{2}$ Bi-metal ion combination demulsification; ${ }^{3}$ Membrane demulsification; ${ }^{4}$ Thermal demulsification [32]; ${ }^{5}$ The equipment investment was calculated by one-time investment based on the average price of water treatment market in China; ${ }^{6}$ The direct operating cost referred to cost of agents and power; ${ }^{7}$ The maintenance charges were calculated at $3 \%$ of the equipment investment [33]. 
For instance, in terms of fixed assets, the minimum initial investment of this research method was USD 3407.80, which could be adopted by both large and small enterprises. In terms of operation, due to the chemical dosing method adopted in this study, there was no need to clean and replace the membrane regularly and not consume huge energy, so the operating cost was far lower than the membrane demulsification and thermal demulsification. However, some problems remain unresolved, such as the ROI (return on investment) index, the cost for the liquid supernatant disposal and the secondary pollutant treatment, i.e., the air pollution control process, etc. Those questions were not only related to the economical aspect but also to the specific environmental equipment manufacturing domain; therefore, we recommended that those unsolved dilemmas be evaluated in the LCC (Life Cycle Cost) or LCA (Life Cycle Assessments) points of view, which will be reported in our further works.

\section{Conclusions}

The effect of mono/bi-metal cations on the single/synergistic demulsification of scrap metal working fluid as an inorganic demulsifier was inspected in the study, the operating parameters of the optimum combination were optimized and the results were as follows. Firstly, $\mathrm{Al}^{3+}$ played a role in increasing the removal of $\mathrm{COD}_{\mathrm{Cr}}$ and the effluent transmittance, $\mathrm{Fe}^{3+}$ played a role in generating the minimum yield of sludge, $\mathrm{Fe}^{2+}$ played a role in generating the maximum $\mathrm{COD}_{\mathrm{Cr}} / \mathrm{SV}_{30}$ ratio and the ion strength had a huge effect on the L-MWFs' demulsification effect, especially promoting the degradation of $\mathrm{COD}_{\mathrm{Cr}}$ and increasing the effluent transmittance. Secondly, the bi-metal combined demulsification of $\mathrm{Al}^{3+}$ and $\mathrm{Fe}^{3+}$ or $\mathrm{Fe}^{2+}$ showed significant synergistic effects. When $\mathrm{Al}^{3+}: \mathrm{Fe}^{3+}=1.5: 1$ was selected, the optimum operating conditions were as follows: the total ion concentration was $0.08 \mathrm{~mol} / \mathrm{L}$, $\mathrm{pH}$ was 6.00 , the stirring time was $18 \mathrm{~min}$ and the temperature was $323 \mathrm{~K}$. The $\mathrm{COD}_{\mathrm{Cr}}$ removal of the supernatant of the L-MWFs was $80.21 \%$, the $\mathrm{SV}_{30}$ ratio was $40.00 \%$, the transmittance was $95.20 \%$ and the $\mathrm{COD}_{\mathrm{Cr}} / \mathrm{SV}_{30}$ ratio was $128.33 \mathrm{mg} / \mathrm{mL}$. Under the optimum conditions, in terms of the total cost for 10 years, the proposed bi-metal ion combination demulsification treatment was about one-seventh the cost of membrane demulsification and about half of the cost of thermal demulsification, which exert a significant economic effect.

Supplementary Materials: The following are available online at https:/ / www.mdpi.com/article/10 .3390/pr9101807/s1, Figure S1: The images of L-MWFs before (left) and after(right) the pretreatment. Figure S2: The supernatant gradually turned red at $\mathrm{pH}$ was 10.00 (left) and 12.00 (right).

Author Contributions: Conceptualization, Y.Q. and Y.Z.; methodology, L.W. and X.Z.; software, L.W.; validation, Y.Q. and B.G.; formal analysis, Y.Q.; investigation, L.W.; resources, B.G.; data curation, X.Z.; writing—original draft preparation, L.W.; writing-review and editing, Y.Z.; visualization, Y.Q. and L.W.; supervision, Y.Q.; project administration, Y.Q.; funding acquisition, Y.Q. All authors have read and agreed to the published version of the manuscript.

Funding: This research was funded by Key Research and Development Program (Major technical innovation projects) of Shandong Provence (No. 2020CXGC011204), The Postgraduate Scholarship Program of China Scholarship Council, CSC 2020, (No. 202000810011). Taodu Elite Program of Yixing City (No.CX201909C), Jiangsu provincial policy guidance program (International Science and technology cooperation) - key national industrial technology research and development cooperation projects (No. BZ2018033).

Institutional Review Board Statement: This study not applicable for studies involving humans or animals.

Informed Consent Statement: This study not applicable for studies involving humans or animals.

Data Availability Statement: The raw/processed data required to reproduce these findings cannot be shared at this time as the data also forms part of an ongoing study. 
Acknowledgments: All authors would like to thank Xu Chang, the CEO of Jiangsu ATK Environmental Engineering Co., Ltd. as well as Wu zhiren, the researcher fellow of School of Environmental Safety and Engineering, Jiangsu University, for the constructive engineering application oriented guidance of them.

Conflicts of Interest: The authors declare no conflict of interest.

\title{
Abbreviations
}

\author{
L-MWFs Long-time used metalworking fluids \\ $\mathrm{SV}_{30}$-ratio Volume ratio of sludge after standing for $30 \mathrm{~min}$ (in percentage, \%) \\ $\mathrm{COD}_{\mathrm{Cr}} / \mathrm{SV}_{30}$-ratio To evaluate the relationship between removal of organic pollutants and \\ yield of secondary sludge
}

\section{References}

1. Cetin, M.H.; Kilincarslan, S.K. Effects of cutting fluids with nano-silver and borax additives on milling performance of aluminium alloys. J. Manuf. Process. 2020, 50, 170-182. [CrossRef]

2. $\quad$ Bi, A.; Tan, Z.; Wang, L.; Li, W.; Liu, C.; Wang, Z.; Liu, X.; Jia, X. The demulsification properties of cationic hyperbranched polyamidoamines for polymer flooding emulsions and microemulsions. Processes 2020, 8, 176. [CrossRef]

3. Osama, M.; Singh, A.; Walvekar, R.; Khalid, M.; Gupta, T.C.S.M.; Yin, W.W. Recent developments and performance review of metal working fluids. Tribol. Int. 2017, 114, 389-401. [CrossRef]

4. Najiha, M.S.; Rahman, M.M.; Yusoff, A.R. Environmental impacts and hazards associated with metal working fluids and recent advances in the sustainable systems: A review. Renew. Sustain. Energy Rev. 2016, 60, 1008-1031. [CrossRef]

5. Waydande, R.; Ghatge, D. Performance evaluation of different types of cut-ting fluids in the machining of hardened steel-A review. Int. J. Mech. Prod. Eng. 2016, 4, 34-39.

6. Directory of National Hazardous Wastes; Version 2021; Communiqu of the State Council, Ministry of Ecology and Environment, PRC: Beijing, China, 2021; pp. 18-46.

7. Yongjiao, X.; Baoqiang, W.; Xiangfeng, H.; Chenlu, L.; Bin, L.; Jia, L.; Lijun, L.; Shiyang, L.; Kaiming, P. Coupling magnetic particles with flocculants to enhance demulsification and separation of waste cutting emulsion for engineering applications. J. Environ. Sci. 2021, 105, 173-183.

8. Zolfaghari, R.; Fakhru'l-Razi, A.; Abdullah, L.C.; Elnashaie, S.S.; Pendashteh, A. Demulsification techniques of water-in-oil and oil-in-water emulsions in petroleum industry. Sep. Purif. Technol. 2016, 170, 377-407. [CrossRef]

9. Qi, Y.; Guo, C.; Xu, X.; Gao, B.; Yue, Q.; Jiang, B.; Qian, Z.; Wang, C.; Zhang, Y. Co/Fe and Co/Al layered double oxides ozone catalyst for the deep degradation of aniline: Preparation, characterization and kinetic model. Sci. Total Environ. 2020, 715, 136982. [CrossRef]

10. Qi, Y.; Ge, B.; Zhang, Y.; Jiang, B.; Wang, C.; Akram, M.; Xu, X. Three-dimensional porous graphene-like biochar derived from Enteromorpha as a persulfate activator for sulfamethoxazole degradation: Role of graphitic $\mathrm{N}$ and radicals transformation. J. Hazard. Mater. 2020, 399, 123039. [CrossRef] [PubMed]

11. Kaszycki, P.; Petryszak, P.; Supel, P. Bioremediation of a spent metalworking fluid with auto- and allochthonous bacterial consortia. Ecol. Chem. Eng. 2015, 22, 285. [CrossRef]

12. Zhou, Y.; Zheng, H.; Huang, Y.; Zheng, X.; Liu, Z.; An, Y.; Zhao, C.; Liu, Y. Hydrophobic modification of cationic microblocked polyacrylamide and its enhanced flocculation performance for oily wastewater treatment. J. Mater. Sci. 2019, 54, 10024-10040. [CrossRef]

13. Abdulredha, M.M.; Hussain, S.A.; Abdullah, L.C. Separation emulsion via non-ionic surfactant: An optimization. Processes 2019, 7, 382. [CrossRef]

14. Putatunda, S.; Bhattacharya, S.; Sen, D.; Bhattacharjee, C. A review on the application of different treatment processes for emulsified oily wastewater. Int. J. Environ. Sci. Technol. 2019, 16, 2525-2536. [CrossRef]

15. Sun, Y.; Zhu, C.; Zheng, H.; Sun, W.; Xu, Y.; Xiao, X.; You, Z.; Liu, C. Characterization and coagulation behavior of polymeric aluminum ferric silicate for high-concentration oily wastewater treatment. Chem. Eng. Res. Des. 2017, 119, 23-32. [CrossRef]

16. Ismail, I.; Kazemzadeh, Y.; Sharifi, M.; Riazi, M.; Malayeri, M.R.; Cortés, F. Formation and stability of W/O emulsions in presence of asphaltene at reservoir thermodynamic conditions. J. Mol. Liq. 2019, 299, 112125. [CrossRef]

17. Hu, G.; Li, J.; Thring, R.W.; Arocena, J. Ultrasonic oil recovery and salt removal from refinery tank bottom sludge. J. Environ. Sci. Health 2014, 49, 1425-1435. [CrossRef] [PubMed]

18. Xu, C.; Yan, F.; Wang, M.; Yan, H.; Cui, Z.; Li, J.; He, B. Fabrication of hyperbranched polyether demulsifier modified PVDF membrane for demulsification and separation of oil-in-water emulsion. J. Membr. Sci. 2020, 602, 117974. [CrossRef]

19. Saad, M.A.; Kamil, M.; Abdurahman, N.H.; Yunus, R.M.; Awad, O.I. An overview of recent advances in state-of-the-art techniques in the demulsification of crude oil emulsions. Processes 2019, 7, 470. [CrossRef]

20. Li, J.; Wang, C.; Tang, Q.; Zhai, M.; Wang, Q.; Shi, M.; Li, X. Preparation and application of supported demulsifier PPA@SiO2 for oil removal of oil-in-water emulsion. Sep. Sci. Technol. 2020, 55, 2538-2549. [CrossRef] 
21. Shen, J.; Liu, B.; Wu, J.; Chai, Y.; Cheng, C.; Liu, C.; Yan, R.; Farooq, S.K.M. Characterization of fluorescent dissolved organic matters in metalworking fluid by fluorescence excitation-emission matrix and high-performance liquid chromatography. Chemosphere 2020, 239, 124703. [CrossRef]

22. Gao, T.; Gu, G. Water Pollution Control and Engineering, 4th ed.; Higher Education Press: Beijing, China, 2015 ; pp. 108-110.

23. Bal, V. Coagulation behavior of spherical particles embedded in laminar shear flow in presence of DLVO-and non-DLVO forces. J. Colloid Interface Sci. 2020, 564, 170-181. [CrossRef]

24. Fang, J.; Cheng, L.; Hameed, R.; Jin, L.; Wang, D.; Owens, G.; Lin, D. Release and stability of water dispersible biochar colloids in aquatic environments: Effects of pyrolysis temperature, particle size, and solution chemistry. Environ. Pollut. 2020, $260,114037$. [CrossRef] [PubMed]

25. Hidehiro, K.; Motoyuki, I. Surface modification and characterization for dispersion stability of inorganic nanometer-scaled particles in liquid media. Sci. Technol. Adv. Mater. 2010, 11, 044304. [CrossRef]

26. Humphreys, B.A.; Wanless, E.J.; Webber, G.B. Effect of ionic strength and salt identity on poly (N-isopropylacrylamide) brush modified colloidal silica particles. J. Colloid Interface Sci. 2018, 516, 153-161. [CrossRef] [PubMed]

27. Tansel, B. Significance of thermodynamic and physical characteristics on permeation of ions during membrane separation: Hydrated radius, hydration free energy and viscous effects. Sep. Purif. Technol. 2012, 86, 119-126. [CrossRef]

28. Tong, K.; Zhang, Y.; Chu, P.K. Evaluation of calcium chloride for synergistic demulsification of super heavy oil wastewater. Colloids Surf. A Physicochem. Eng. Asp. 2013, 419, 46-52. [CrossRef]

29. Liu, L.; Yang, Q.; Wang, P.; Xiao, F.; Jiao, R.; An, G.; Wang, D. Efficient purification of Al (30) by organic complexation method. J. Environ. Sci. 2019, 80, 240-247. [CrossRef] [PubMed]

30. Liu, Z.; Duan, X.; Zhan, P.; Liu, R.; Nie, F. Coagulation performance and microstructural morphology of a novel magnetic composite coagulant for pre-treating landfill leachate. Int. J. Environ. Sci. Technol. 2017, 14, 2507-2518. [CrossRef]

31. Binner, E.R.; Robinson, J.P.; Silvester, S.A.; Kingman, S.W.; Lester, E.H. Investigation into the mechanisms by which microwave heating enhances separation of water-in-oil emulsions. Fuel 2014, 116, 516-521. [CrossRef]

32. Chinese Government Procurement Website. Available online: http:/ /www.ccgp.gov.cn (accessed on 11 September 2021).

33. Sun, J. Application Study of Life Cycle Cost Analysis on Industrial Wastewater Treatment Engineering Project; Shanghai JiaoTong University: Shanghai, China, 2011. (In Chinese) 